\title{
ANALISIS FAKTOR YANG MEMENGARUHI PEMBERIAN MPASI DINI
}

\author{
Budi Artini \\ Sekolah Tinggi Ilmu Kesehatan William Booth \\ Email: budiartini410@gmail.com
}

\begin{abstract}
ABSTRAK
MPASI (Makanan pendamping ASI) merupakan pemberian makanan pendamping selain ASI saat bayi berusia 6 bulan. Dalam pemberian MPASI dini terdapat 2 faktor utama yang mempengaruhi, yaitu faktor internal dan faktor eksternal. Faktor internal meliputi : pengetahuan dan pengalaman dan faktor eksternal meliputi : sosial budaya, petugas kesehatan dan informasi. Penelitian ini bertujuan untuk mengetahui faktor-faktor yang mempengaruhi pemberian MPASI Dini di RW A. Penelitian yang dilakukan menggunakan metode deskriptif dengan populasi seluruh ibu yang sudah memberikan MPASI dini pada bayi usia 0-1 tahun. Sampel berjumlah 26 Orang. Data diolah dengan mengunakan distribusi frekuensi. Hasil Penelitian menunjukkan bahwa semua faktor baik internal dan eksternal mempengaruhi pemberian MPASI Dini. Faktor Internal yang meliputi Pengetahuan yaitu sebanyak 26 responden (100\%) dan Pengalaman yaitu sebanyak 23 responden $(88,5 \%)$ sedangkan faktor eksternal yang meliputi faktor sosial budaya yaitu sebanyak 24 responden yaitu $(92,3 \%)$, faktor petugas kesehatan yaitu sebanyak 25 responden $(96,2 \%)$ dan faktor informasi yaitu sebanyak 26 responden (100\%) dengan Faktor Dominan yang mempengaruhi pemberian MPASI dini yaitu faktor pengetahuan dan informasi yaitu sebanyak 26 responden $(100 \%)$. Disarankan perlu adanya peningkatan frekuensi penyuluhan tentang pentingnya ASI Eksklusif dan Manfaat ASI di masyarakat oleh Instansi kesehatan setempat dengan melakukan kerjasama dengan melibatkan semua komponen yang ada.
\end{abstract}

Kata Kunci : $\quad$ MPASI dini, Faktor Pengetahuan, Faktor Pengalaman, Faktor Sosial Budaya, Faktor Petugas Kesehatan dan Faktor Informasi.

\begin{abstract}
MPASI (Attentions associate food) constituting associate alimentary application besides Attention while baby gets age 6 months. In MPASI'S application early exists 2 prime factor that regards, which is internal factor and external factor. Factor internaling to cover: science and experience and external factor covers: cultural social, health and information officer. This research intent to know factor that regard MPASI'S application Early at RW A. Research that doing to utilize Descriptive method with mothers exhaustive population already give early MPASI on age baby 01 year. Total sample 26 Person. Data at o with using frequency distribution. Result Observationaling to point out that all good factor internal and external regard MPASI'S application Early. Internal factor that cover Science which is as much 26 respondents (100\%) and Experience which is as much 23 respondents (88,5\%) meanwhile external factor that cover social factor culturizes which is as much 24 respondents which is (92,3\%), health officer factor which is as much 25 respondents (96,2\%) and information factor which is as much 26 respondents (100\%) with Dominant Factor that regard MPASI'S application early which is science and information factor which is as much 26 respondents (100\%). Suggested to need marks sense counselling frequency step-up about the importance for Exclusive Attention and Attention Benefit at society by local health Institution by undertaking collaboration by involves all aught component.
\end{abstract}

Key Words : MPASI'S application Early, science factor, experience factor, cultural social factor, health officer factor, information factor 


\section{PENDAHULUAN}

ASI merupakan nutrisi yang optimal bagi bayi dan merupakan makanan yang ideal untuk sistem pencernaan bayi yang sedang berkembang. Selain itu, ASI memberikan proteksi terhadap beberapa penyakit infeksi tertentu yang berpotensi menyerang bayi pada minggu-minggu pertama kehidupan (MIMS Bidan, 2012). ASI eksklusif menurut WHO (World Health Organization) adalah pemberian ASI saja tanpa tambahan cairan lain baik susu formula, air putih, air jeruk, ataupun makanan tambahan lain. MPASI (Makanan pendamping ASI) merupakan pemberian makanan pendamping selain ASI saat bayi berusia 6 bulan. ASI hanya menyediakan setengah atau lebih kebutuhan gizi bayi pada usia 6-12 bulan. Memasuki 1214 bulan, ASI hanya menyediakan sepertiga dari kebutuhan gizinya. Untuk itu bayi perlu mendapatkan MPASI untuk mencukupi kebutuhan zat gizi tubuhnya (Dian Rakyat, 2012).

Dalam pemberian MPASI dini terdapat 2 faktor utama yang mempengaruhi, yaitu faktor internal dan faktor eksternal. Faktor internal meliputi : pengetahuan dan pengalaman dan faktor eksternal meliputi : sosial budaya, petugas kesehatan dan informasi. Apabila orang tua memiliki pengetahuan yang baik tetang pentingnya pemberian ASI, maka akan mantap untuk memberikan ASI saja sampai bayi berusia 6 bulan, sebaliknya jika orang tua tidak memiliki pengetahuan yang adekuat maka orang tua tidak mengerti tentang pentingnya pemberian ASI, sehingga agar bayi kenyang MPASI diberikan terlalu dini (Notoatmodjo, 2005). Pada kebanyakan wanita terbiasa menggunakan susu formula dengan pertimbangan lebih modern dan praktis, juga karena mereka tidak pernah melihat model menyusui ASI dari lingkungannya (Briawan, 2004). Budaya masyarakat yang memberikan dampak yang negatif dengan adanya MPASI yang seharusnya diberikan pada bayi usia 6 bulan keatas, tetapi sudah diberikan pada usia kurang dari 6 bulan saat bayi mendapat upacara 1 bulanan dan 3 bulanan. Petugas kesehatan sebagai "educator" peran ini dilaksanakan dengan membantu klien dalam meningkatkan tingkat pengetahuan sehingga terjadi perubahan tingkah laku dari klien setelah dilakukan pendidikan kesehatan (Wahid Iqbal, 2005). Kebanyakan ibu pada kehamilan pertama tidak diberi informasi tentang manfaat ASI dan kolostrum. Banyak Ibu tidak mengetahui manfaat pemberian ASI eksklusif. Para ibu percaya bahwa campuran susu formula dengan ASI baik untuk bayinya (Briawan, 2004).

Fenomena yang ditemukan peneliti di RW A, ditemukan banyak bayi yang berusia dibawah 6 bulan sudah diberikan makanan pendamping seperti pisang kerok dan bubur susu disamping itu pemberian MPASI dini dilakukan kebanyakan orang tua dengan berbagai alasan, diantaranya yang paling sering adalah bayi masih lapar meskipun sudah diberi ASI dan tampak terus rewel, Hal ini juga dipengaruhi oleh pengalaman sebelumnya ibu yang sudah mempunyai anak pertama, meskipun bayi pertama diberikan MPASI dini bayinya tampak sehat dan tidak mengalami gangguan apapun, sehingga untuk bayi yang sekarang ini ibu tidak khawatir untuk memberikan MPASI dini. Lingkungan masyarakat sekitar kebanyakan berasal dari kelas menengah bawah sehingga pengetahuan ibu tentang ASI eksklusif kurang, banyak ibu juga melihat contoh dari para tetangganya yang sudah memberikan MPASI dini pada bayinya, selain itu kebanyakan warga berkebudayaan madura yang memiliki budaya memberikan MPASI secara dini dengan anggapan bayi mereka akan lebih sehat dan gemuk, kurangnya perhatian dari petugas kesehatan yang tetap membiarkan perilaku pemberian MPASI dini juga sangat mempengaruhi masyarakat, sehingga mereka beranggapan hal ini biasa saja atau mungkin diperbolehkan.

Berdasarkan data SDKI (Survei Demografi dan Kesehatan Indonesia), tahun 2002-2003 sebagian bayi sudah mendapatkan makanan / minuman pendamping ASI sejak dini, 36\% bayi berumur kurang dari 2 bulan mendapat makanan pendamping ASI yang terdiri dari air $(4,1 \%)$, cairan lain $(2,7 \%)$, susu non ASI $(16,3 \%)$ dan makanan padat atau lumat $(21,1 \%)$, makanan padat diberikan bayi umur 2-3 bulan. Dari data Dinas kesehatan Jawa Timur menyebutkan selama tahun 2007 dari total bayi 11,01 bayi yang diperiksa terdapat 10,071 bayi yang sudah diberi MPASI sebelum berusia 6 bulan. Berdasarkan Penelitian sebelumnya 
menunjukkan bahwa sebanyak lebih dari $80 \%$ ibu yang tidak memberikan ASI eksklusif selama 6 bulan dan telah memberikan makanan / minuman prelaktal dalam 3 hari pertama kepada bayinya, umumnya berupa susu formula di jawa barat 25,8 \% dan Jawa Timur 15,3\% (Fikawati, 2003). Dari hasil survey awal pada data POSYANDU bulan Desember tahun 2012 di RW 1 Kecamatan Wonokromo Surabaya terdapat 14 bayi yang berusia $0-6$ bulan. Bayi yang berusia $0-6$ bulan $85,71 \%$ (12 bayi) mendapat MPASI dini. Sekitar 7,7\% (2 bayi) yang mengalami gangguan pencernaan sampai dirawat di RSU Daerah.

Pemberian MPASI harus dimulai saat bayi berusia 6 bulan sebab, sebelum usia 6 bulan, enzim pencernaan bayi belum sempurna sehingga bayi belum dapat mencerna zat tepung dan belum sempurna mencerna protein. Akibatnya, enzim yang berfungsi melapisi protein makanan penyebab alergi belum cukup diproduksi, sehingga protein yang masuk ke dalam selsel usus malah merangsang reaksi alergi dan intoleransi. Dibawah 6 bulan, daya imunitas bayi belum sempurna. Akibatnya, pemberian makanan sebelum 6 bulan mengandung kuman-kuman untuk masuk ke dalam tubuhnya. Bayi menjadi lebih mudah sakit, mulai dari sakit, batuk, pilek, demam, sembelit, atau diare. Bila keadaan ini sering terjadi akan berdampak buruk pada pertumbuhan dan perkembangan bayi, selain itu orang tua juga harus mengeluarkan biaya untuk perawatan bayinya yang sakit (Dian rakyat, 2012).

Untuk menunjang upaya penanggulangan masalah faktor-faktor yang mempengaruhi pemberian MPASI dini bidan dapat memberikan penyuluhan bekerjasama dengan Ibu rumah tangga, Kader, Petugas PUSKESMAS dan juga para Tokoh masyarakat maupun Tokoh Agama yang dianggap berpengaruh dalam masyarakat sekitar guna membantu penyampaian informasi tentang ASI eksklusif, MPASI dan kapan pemberian MPASI, bidan juga bisa melakukan penyegaran untuk meningkatkan peran serta kader dalam penyelenggaraan pemberian ASI eksklusif bagi para ibu pasca salin sehingga pemberian MPASI dini bisa ditanggulangi. Bidan juga bisa mengajarkan pada para ibu rumah tangga cara menyusui yang benar sehingga ibu bisa melihat secara langsung dan mengubah pengalaman ibu tentang pemberian MPASI dini karena tidak ada model menyusui yang pernah ibu lihat disekitarnya. Penelitian ini bertujuan untuk mengetahui faktor-faktor yang mememngaruhi pemberian MPASI dini di RW A.

\section{BAHAN DAN METODE}

Desain penelitian yang digunakan dalam penelitian ini adalah deskriptif. Populasi menjadi target pada penelitian ini yaitu seluruh ibu yang sudah memberikan MPASI dini pada bayi usia 0-1 tahun di RW A. Besar sampel yang digunakan dalam penelitian ini sesuai dengan kriteria penelitian ini sejumlah 26 ibu. Alat ukur yang digunakan adalah kuesioner dengan menggunaka skala Likert. Analisa data menggunakan tabulasi silang.

HASIL

Tabel 1 Karakteristik responden

\begin{tabular}{ccc} 
Karakteristik & Jumlah & $\begin{array}{c}\text { Prosentase } \\
(\mathbf{\%})\end{array}$ \\
Pendidikan & & \\
SD & 4 & 15,4 \\
SMP & 4 & 15,4 \\
SMA & 17 & 65,4 \\
PT & 1 & 3,8 \\
Jumlah Anak & & \\
1 & 4 & 15,4 \\
$2-3$ & 15 & 57,7 \\
>3 & 7 & 26,9 \\
Penghasilan & & \\
tiap bulan & 12 & 46,2 \\
Rp 500.000 - & 7 & 26,9 \\
Rp 1.000.000 & 5 & 19,2 \\
Rp 1.100.000 - & 2 & 7,7 \\
Rp 1.500.000 & & \\
Rp 1.600.000 - & 24 & 92,31 \\
Rp 2.000.000 & 2 & 7,69 \\
Rp 2.100.000 - & & \\
Rp 2.500.000 & & \\
Daerah asal & & \\
Jawa & & \\
Madura & & \\
\hline Jumlah & $\mathbf{2 6}$ & $\mathbf{1 0 0}$ \\
\hline
\end{tabular}


Tabel 2 Distribusi frekuensi berdasarkan faktor pengetahuan di RW A

\begin{tabular}{ccc}
\hline Pengetahuan & Jumlah & $\begin{array}{c}\text { Prosentase } \\
(\mathbf{\%})\end{array}$ \\
Mempengaruhi & 26 & 100 \\
Tidak Mempengaruhi & 0 & 0 \\
\hline Jumlah & $\mathbf{2 6}$ & $\mathbf{1 0 0}$ \\
\hline
\end{tabular}

Berdasarkan Tabel 2 menunjukkan bahwa faktor pengetahuan mempengaruhi pemberian MPASI dini yaitu sebanyak 26 responden $(100 \%)$.

Tabel 3 Distribusi frekuensi berdasarkan faktor pengalaman di RW A

\begin{tabular}{ccc} 
Pengalaman & Jumlah & $\begin{array}{c}\text { Prosentase } \\
(\mathbf{\%})\end{array}$ \\
Mempengaruhi & 23 & 88,5 \\
Tidak & 3 & 11,5 \\
Mempengaruhi & & \\
\hline Jumlah & $\mathbf{2 6}$ & $\mathbf{1 0 0}$ \\
\hline
\end{tabular}

Berdasarkan Tabel 3 Menunjukkan bahwa faktor pengalaman mempengaruhi pemberian MPASI dini yaitu sebanyak 23 responden $(88,5 \%)$.

Tabel 4 Distribusi Frekuensi berdasarkan faktor sosial budaya di RW A

\begin{tabular}{|c|c|c|}
\hline Sosial Budaya & Jumlah & $\begin{array}{c}\text { Prosentase } \\
(\%)\end{array}$ \\
\hline $\begin{array}{c}\text { Mempengaruhi } \\
\text { Tidak }\end{array}$ & 24 & 92,3 \\
\hline Mempengaruhi & 2 & 7,7 \\
\hline Jumlah & 26 & 100 \\
\hline
\end{tabular}

Berdasarkan Tabel 4 menunjukkan bahwa faktor sosial budaya mempengaruhi pemberian MPASI dini yaitu sebanyak 24 responden $(92,3 \%)$.

Tabel 5 Distribusi Frekuensi berdasarkan faktor petugas kesehatan di RW A

\begin{tabular}{ccc}
$\begin{array}{c}\text { Petugas } \\
\text { Kesehatan }\end{array}$ & Jumlah & $\begin{array}{c}\text { Prosentase } \\
(\mathbf{\%})\end{array}$ \\
$\begin{array}{c}\text { Mempengaruhi } \\
\text { Tidak }\end{array}$ & 25 & 96,2 \\
Mempengaruhi & 1 & 3,8 \\
\hline Jumlah & $\mathbf{2 6}$ & $\mathbf{1 0 0}$ \\
\hline
\end{tabular}

Berdasarkan Tabel 5 menunjukkan bahwa faktor petugas kesehatan mempengaruhi pemberian MPASI dini yaitu sebanyak 25 responden $(96,2 \%)$.

Tabel 6 Distribusi Frekuensi berdasarkan faktor informasi di RW A

\begin{tabular}{|c|c|c|}
\hline Informasi & Jumlah & $\begin{array}{c}\text { Prosentase } \\
(\%)\end{array}$ \\
\hline Mempengaruhi & 26 & 100 \\
\hline Tidak & 0 & 0 \\
\hline Mempengaruhi & & \\
\hline Jumlah & 26 & $100 \%$ \\
\hline
\end{tabular}

Berdasarkan Tabel 6 menunjukkan bahwa faktor informasi mempengaruhi pemberian MPASI Dini yaitu sebanyak 26 responden $(100 \%)$.

Tabel 7 Distribusi Frekuensi responden berdasarkan faktor dominan yang mempengaruhi pemberian MPASI Dini di RW A

\begin{tabular}{cccc}
\hline Faktor-Faktor & Mempengaruhi & $\begin{array}{c}\text { Jumlah } \\
\text { Tidak } \\
\text { Mempenga } \\
\text { ruhi }\end{array}$ \\
Pengetahuan & $26(100 \%)$ & $0(0 \%)$ & $26(100 \%)$ \\
Pengalaman & $23(88,5 \%)$ & $3(11,5 \%)$ & $26(100 \%)$ \\
Sosial-Budaya & $24(92,3 \%)$ & $2(7,7 \%)$ & $26(100 \%)$ \\
Petugas & $25(96,2 \%)$ & $1(3,8 \%)$ & $26(100 \%)$ \\
Kesehatan & $26(100 \%)$ & $0 \%$ & $26(100 \%)$ \\
Informasi & & &
\end{tabular}
bahwa semua faktor mempengaruhi pemberian MPASI Dini. Faktor yang paling mempengaruhi pemberian MPASI Dini di RW A yaitu faktor pengetahuan dan faktor informasi masing-masing sebanyak 26 responden $(100 \%)$.

\section{PEMBAHASAN}

Berdasarkan Tabel 7 didapatkan hasil bahwa semua faktor mempengaruhi pemberian MPASI Dini baik Faktor Pengetahuan, Pengalaman, Sosial-budaya, Petugas Kesehatan dan Informasi. Faktor yang paling mempengaruhi pemberian MPASI Dini di RW 1 Kelurahan Ngagel Kecamatan Wonokromo Surabaya yaitu faktor pengetahuan dan faktor informasi sebanyak 26 responden (100\%). 
Menurut WHO ( 2003) faktor-faktor yang mempengaruhi pemberian MPASI dini ada 2 yaitu Faktor Internal dan Eksternal. Faktor Internal meliputi : Faktor Pengetahuan dan Pengalaman, sedangkan Faktor Eksternal Meliputi : Sosial-budaya, Petugas Kesehatan dan Informasi. Hal ini menunjukan bahwa dalam pemberian MPASI dini banyak faktor yang mempengaruhi seseorang untuk memberikan MPASI dini baik dari diri orang tersebut maupun dari lingkungan tempat mereka tinggal sehingga diharapkan adanya upaya-upaya yang dilakukan untuk mencegah pemberian MPASI dini.

Faktor Pengetahuan

Berdasarkan hasil penelitian didapatkan faktor pengetahuan mempengaruhi pemberian MPASI dini yaitu sebanyak 26 responden (100\%). Menurut Notoatmodjo (2007), pengetahuan adalah merupakan hasil dari tahu dan ini setelah orang melakukan penginderaan terhadap obyek tertentu. Penginderaan terjadi melalui panca indera manusia, yakni indera penglihatan, pendengaran, penciuman, rasa dan raba. Sebagaian besar pengetahuan manusia diperoleh melalui mata dan telinga. Jika dilihat dari tabel 1 karakteristik responden berdasarkan tingkat pendidikan terbanyak ibu berpendidikan SMA yaitu sebanyak 17 orang $(65,7 \%)$. Hal ini menunjukkan bahwa ibu dengan pendidikan SMA mampu diharapkan sudah mampu mencari, menerima dan menyerap informasi dengan baik namun kenyataannya ibu dengan pendidikan SMA masih banyak yang memberikan MPASI dini hal ini dapat dikarenakan bahwa pengetahuan tidak selalu diperoleh dari pendidikan formal tapi bisa melalui pendidikan nonformal maupun media massa dan elektronik. Pada masa sekarang banyak media massa maupun elektronik menayangkan informasi yang membuat ibu tertarik sehingga akan mempengaruhi pengetahuan ibu dalam pemberian MPASI Dini. Jika dilihat dari segi penampilan, dengan pengetahuan yang baik mereka akan lebih memilih memberikan MPASI dini dikarenakan ibu takut dengan menyusui bayinya akan membuat payudaranya kendor terlebih lagi pada ibu yang bekerja sehingga ia akan lebih memperhatikan penampilannya.
Faktor Pengalaman

Berdasarkan hasil penelitian didapatkan bahwa sebagian besar faktor pengalaman mempengaruhi pemberian MPASI dini yaitu sebanyak 23 responden $(88,5 \%)$. Menurut Notoadmojo (2005) mengatakan bahwa pengalaman pribadi masa lalu akan membawa seseorang memecahkan masalah bila dihadapkan dengan pengalaman dimasa yang akan datang. Berdasarkan tabel 1 karakteristik responden berdasarkan jumlah anak menunjukkan bahwa terbanyak ibu dengan jumlah anak 2-3 orang anak sebesar 15 orang $(57,5 \%)$. Ibu yang sudah pernah mempunyai anak lebih dari satu cenderung akan memiliki pengalaman yang cukup dalam mengasuh anaknya termasuk dalam hal pemberian MPASI Dini, kemungkinan ibu sebelumnya sudah pernah memberikan MPASI Dini namun tidak terjadi masalah pada bayinya sehingga ibu akan membawa pengalaman itu untuk diterapkan pada anak selanjutnya.

\section{Faktor Sosial Budaya}

Berdasarkan hasil penelitian tabel 4 didapatkan bahwa sebagian besar faktor sosial budaya mempengaruhi pemberian MPASI dini yaitu sebanyak 25 responden (92,3\%). Menurut Notoadmodjo (2005), Sosio budaya (culture) setempat biasanya sangat berpengaruh terhadap terbentuknya perilaku seseorang. Jika dilihat dari tabel 1 karakteristik responden berdasarkan daerah asal sebanyak 24 responden $(92,31 \%)$ Hal ini sesuai dengan perilaku ibu dalam pemberian MPASI Dini juga dipengaruhi oleh sosio budaya setempat dimana terdapat kepercayaan, adat istiadat maupun kebiasaan masyarakat setempat, dalam adat istiadat jawa ada tradisi 3 bulanan dimana bayi diberikan bubur susu ataupun pisang kerok karena bayi dianggap sudah mampu untuk menerina MPASI saat upacara 3 bulanan tersebut. Selain itu orang tua memberikan MPASI dini karena menurut mereka bayi yang sering menangis walaupun sudah diberi ASI menunjukkan bayi masih lapar sehingga harus diberi makananan tambahan selain ASI seperti pisang ataupun nasi yang dilumatkan.

Faktor Petugas kesehatan

Berdasarkan hasil penelitian tabel 5 didapatkan bahwa sebagian besar faktor petugas kesehatan mempengaruhi pemberian 
MPASI dini yaitu sebanyak 25 responden (96,2\%). Petugas kesehatan sebagai "educator" peran ini dilaksanakan dengan membantu klien dalam meningkatkan tingkat pengetahuan kesehatan, sehingga terjadi perubahan tingkah laku dari klien setelah dilakukan pendidikan kesehatan (Wahid Iqbal, 2005 : 76). Pada kenyataan masih banyak ibu yang memberikan MPASI dini hal ini dapat dikarenakan kurangnya pemantauan dari petugas kesehatan dalam pemberian MPASI Dini ataupun tidak ada langkah lanjutan yang dilakukan oleh petugas kesehatan dalam penyelesaian masalah MPASI dini, selain itu luasnya jangkauan wilayah kerja petugas kesehatan disertai dengan jumlah penduduk yang banyak sedangkan jumlah petugas kesehatan itu sendiri tidak sesuai dengan luas wilayah sehingga penanganan dan pemantauan oleh petugas pun tidak akan maksimal.

\section{Faktor Informasi}

Berdasarkan hasil penelitian tabel 6 didapatkan bahwa keseluruhan faktor informasi mempengaruhi dalam pemberian MPASI Dini yaitu sebanyak 26 responden (100\%). Informasi Menurut George $\mathrm{H}$. Bodnar, (2000: 1), "Informasi adalah data yang diolah sehingga dapat dijadikan dasar untuk mengambil keputusan yang tepat". Dalam era globalisasi ini terjadi kemajuan ilmu pengetahuan dan pesatnya tehnologi sehingga ibu pun akan semakin mudah dalam mendapatkan informasi, salah satu contoh adalah banyaknya iklan-iklan susu formula yang menawarkan berbagai produk dengan berbagai kelebihan akan membuat ibu tertarik untuk memberikan MPASI Dini.

Faktor Dominan

$\begin{array}{ccr}\text { Berdasarkan hasil penelitian } \\ \text { didapatkan bahwa } & \text { semua faktor }\end{array}$
mempengaruhi pemberian MPASI Dini. Faktor yang paling mempengaruhi pemberian MPASI Dini di RW 1 Kelurahan Ngagel Kecamatan Wonokromo Surabaya yaitu faktor pengetahuan dan faktor informasi sebanyak 26 responden (100\%). Abdul Kadir (2002: 31); McFadden dkk (1999) mendefinisikan informasi sebagai data yang telah diproses sedemikian rupa sehingga meningkatkan pengetahuan seseorang yang menggunakan data tersebut. Pada zaman ini, dengan semakin berkembangnya ilmu pengetahuan dan juga cepatnya akses informasi sehingga ibu akan cenderung meniru apapun informasi yang ia dapatkan sehingga mempengaruhi pengetahuannya, selain itu banyaknya iklan-iklan susu formula dan informasi makanan tambahan yang ada di berbagai media dengan menawarkan berbagai keunggulan akan mempengaruhi pengetahuan ibu untuk pemberian MPASI Dini karena mereka beranggapan susu formula lebih baik dari ASI dan ASI saja tidak cukup untuk memenuhi kebutuhan bayinya. Dilihat dari tabel 1 berdasarkan karakteristik responden berdasarkan penghasilan tiap bulan pengahasilan ibu terbanyak adalah Rp.500.000$1.000 .000 /$ bulan yaitu sebanyak 12 responden $(46,2 \%)$ hal ini menunjukkan bahwa ibu yang memiliki penghasilan sendiri akan lebih memilih untuk memberikan MPASI terutama susu formula pada bayinya karena mereka merasa mampu untuk membeli.

\section{SIMPULAN}

Dari hasil penelitian dapat disimpulkan bahwafaktor pengetahuan, faktor pengalaman, faktor sosial budaya, faktor petugas kesehatan dan faktor informasi mempengaruhi pemberian MPASI dini. Faktor dominan yang memengaruhi pemberian MPASI dini adalh faktor pengetahuan dan informasi.

\section{SARAN}

Bagi mahasiswadan dosen diharapkan pada saat melakukan program pengabdian kepada masyarakat dengan memberikan pendidikan kesehatan serta informasi terkini dalam kesehatan sehingga dapat menambah pengetahuan masyarakat agar mereka akan memberikan MPASI setelah 6 bulan pemberian ASI eksklusif.. Bagi Ketua RW diharapkan dapat bekerjasama dengan instansi kesehatan seperti puskesmas untuk bisa mengadakan penyuluhan-penyuluhan kesehatan tentang ASI Eksklusif, dan dampak pemberian MPASI Dini serta meningkatkan peran kader sebagai tangan panjang dari petugas kesehatan sehingga informasi yang diberikan dapat disebarluaskan di masyarakat.

\section{DAFTAR PUSTAKA}


Admin, 2010. Makanan Pendamping ASI. WWW// http : makanan pendamping ASI.com. tanggal 17 Oktober 2011. Jam 16.00 WIB

Alimul, Aziz. 2008. Pengantar Ilmu Kesehatan Anak. Jakarta : Salemba Medika

Barasi, Mary.E. 2007. ILMU GIZI. Jakarta : Erlangga

Chandra. 2005. Metode Penelitian Kesehatan. Jakarta : EGC

Donna, L.Wong. 2008. Buku Ajar keperawatan Pediatrik, Volume 1, Edisi 6, Jakarta : EGC

Friedman. 2004. Keperawatan keluarga. Jakarta : EGC

Nursalam. 2005. Asuhan Keperawatan bayi dan Anak, Edisi Pertama, Jakarta : Salemba Medika 2008. Konsep dan Penerapan Metodologi Penelitan Ilmu Keperawatan, Edisi III . Jakarta: Salemba Medika.

Soekidjo, Notoadmodjo. 2002. Metodelogi Penelitian Kesehatan. Jakarta : PT Rineka Cipta

2005. Metodologi Penelitian Kesehatan. Jakarta: PT Rineka Cipta

2007. Promosi kesehatan dan Ilmu Perilaku. Jakarta : PT Rineka Cipta

Soeginjanto, Soegeng. 2002. Ilmu penyakit Anak, Diagnosa dan Penatalaksanaan, Edisi pertama, Jakarta : Salemba Medika

Sugiyono, 2006. Statistika untuk Penelitian. Bandung: CV. Alfa Beta.

Tim penyusun Dian rakyat. 2012. MPASI Dapur Ibu. Jakarta : Dian Rakyat

Tim Penyusun Kamus Pusat. 2002. Kamus Besar bahasa Indonesia. Jakarta : Balai Pustaka 